\title{
腎細胞癌の治療成績
}

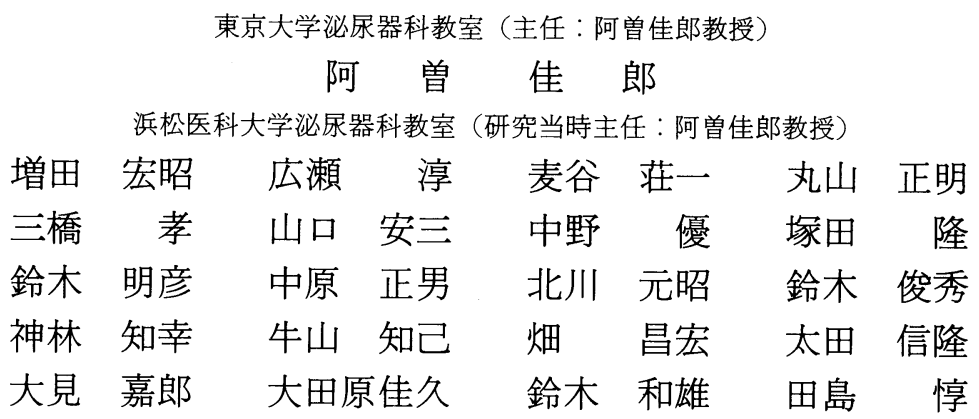

\section{THE RESULTS OF TREATMENT FOR RENAL CELL CARCINOMA}

\author{
Yoshio Aso \\ Department of Urology, Faculty of Medicine, The University of Tokyo \\ (Chairman: Prof. Y. Aso)
}

Hiroaki Masuda, Jun Hirose, Souichi Mugiya, Masaaki Maruyama, Takashi Mitsuhashi,

Yasuzou Yamaguchi, Masaru Nakano, Takashi Tsukada, Akihiko Suzuki,

Masao Nakahara, Motoaki Kitagawa, Toshihide Suzuki, Tomoyuki Kanbayashi,

Tomomi Ushiyama, Masahiro Hata, Nobutaka Ohta, Yoshirou Ohmi,

Yoshihisa Ohtawara, Kazuo Suzuki and Atushi Tajima

Department of Urology, Hamamatsu University School of Medicine

(Chairman: Prof. Y. Aso)

The present study reports the results of treatment in 67 cases of renal cell carcinoma during the 10 years from 1977 to 1987. Overall 1, 3 and 5-year survival rates by Kaplan-Meier method were 79.8, 64.1 and 55.5 percents, respectively.

Several factors which might be related to prognosis were analysed. As a result, anemia, increased erythrocyte sedimentation rate, postive $\mathrm{C}$-reactive protein, decreased serum albumin, elevated serum $\alpha_{1}$-globlin and mixed echo pattern were found to be poor prognostic factors. By pathological study, the stage and the histological grade of tumors were found to be significant prognostic factors, while the importance of cell type, structual pattern and microinfiltration as a prognostic factor was not clearly demonstrated.

The cases with renal cell carcinoma were treated with the combined adjuvant therapy of chemotherapy (FT 207, 5-FU or UFT) and nonspecific immunotherapy (OK-432: Picibanil) postoperatively. It appeared that the postoperative adjuvant therapy was useful for the improvement of prognosis. 
れたが有意ではなかった。病理学的検討では, 腫瘍の進展度と悪性度は予後に影響する重要な因子であっ たが, 腎癌の細胞型, 構築型, 浸潤増殖様式が予後因子か否かははっきりしなかった。われわれは腎癌 の根治的腎摘除術後に, 化学療法(FT207, 5-FU またはUFT) と非特異的免疫療法(OK-432: Picibanil) を併用した補助療法を行っているが, この補助療法は腎癌の予後改善に有用と思われた。進行腎癌に投 与された Interferon- $\alpha$ の生存率に対する効果については少数例のため明らかにすることはできなかっ た.

\section{緒言}

腎細胞癌 (以下腎癌) は腎腫瘍の中では最も多い腫 瘍であるが，その予後は必ずしも良好とはい方ない。 特に, 進行腎癌の予後は不良で, 最近はインターフェ ロンも使われているが1)，その臨床効果は必ずしも十 分なものではない。季た，進行がきわめてゆっくりで あったり (slow growing), 原発巣摘出後, 転移が消失 することがあるなど特異な経過をたどる場合があるこ とが知られている21.

現在までも腎癌の臨床成績は，しばしば報告されて はいるが，われわれも浜松医科大学泌尿器科学教室開 設以来の 10 年間の治療成績を検討したので報告する。

\section{対象・方法}

1977年11月から 1987 年 6 月までの約 10 年間に浜松医 科大学掞よび関連病院泌尿器科で臨床的に腎癌と診断 され，治療した症例は76例であった。しかし，手術ま たは剖検により組織学的に腎癌と確定診断されたもの は67例で，他の 9 例についてみると，手術，剖検を行 えなかったもの 6 例, 手術不能で剖検を行ったがその 結果がまだ報告されていないもの 3 例となっている. 今回の検討では, 組織学的に腎癌と確認されている症 例67例だけを対象とした。その67症例の内訳は，男52 例，女 15 例，年歯38歳から 84 歳(平均年齢62.4歳), 患 側は右側28例, 左側39例であった。観察期間は 3 力月 から 8 年 9 カ月である.

67例の腎癌のうち, 遠隔転移がなく治癒的な根治的 腎摘除術を施行できた症例は46例，遠隔転移があるた め非治癒的な単純腎摘除術を施行した症例は13例で あった．他の 8 例は試験手術のみが 2 例, 超音波断層 法による穿刺 1 例，手術を行わず剖検により組織学的 診断を行った症例が 5 例であった。根治的腎摘除術後 の術後補助療法としては, 原則的には化学療法 (FT 207,5-FU または UFT) と非特異的免疫療法(OK-432) の併用を行っている。一方, 遠隔転移を有する進行腎 癌に対して行った単純腎摘除術の術後には，初期は木 ルモン療法 (medroxyprogesterone acetate), 1983年 9 月からはインターフェロン (IFN)を投与している.
これらの腎癌症例について, 1987年 6 月 30 日におけ る生死を確認し生存率を計算して, 初発症状, 臨床検 查所見, 画像診断所見, 病理学的所見, 治療法による 予後について検討した。生存率は Kaplan-Meier 法で 計算し, 起算日は初診日とした。術後 1 カ月以内に死 亡した術後死は 3 例あり, この 3 例は生存率の計算か らは除外した。術後死の原因は, 術中の出血による DIC のため術後 2 日目に死亡したものが 2 例, 術後 10 日目に脳梗塞のため死亡したものが 1 例であった。 た病理学的所見は，腎癌取扱い規約にしたがった ${ }^{3)}$.な 打検定は $\chi^{2}$ 検定に Y ates の連続補正を加光，危険率 $5 \%$ で行った.

\section{結果}

\section{1. 全症例の生存率}

まず腎癌67例のうち, 術後死の 3 例を除く64例の生 存率を示す(図 1 )。1 年生存率は $79.8 \%$ で，その後は 徐々に低下し，3 年生存率 $64.1 \% ， 5$ 年生存率 $55.5 \%$ であった。

\section{2. 初発症状による生存率}

腎癌の初発症状には, いわゆる三大症状の血尿, 側 腹部痛, 腫瘤を示寸症例（尿路症状群）の他に, 体重 減少, 易疲労感, 発熱などの尿路外症状を呈する症例 （尿路外症状群）がある。また近年は検診の普及により， 無症状のうちに偶然に超音波断層法で発見されて腎癌 と診断される症例 (偶然群) がある4). 本集計では, 尿 路症状群 43 例, 尿路外症状群 13 例, 偶然群11例であっ た。その生存率を示したものが図 2 である，有意では ないが，偶然群は早期に診断されるため予後が良好で あるのに対し, 尿路外症状群は予後不良の傾向が示さ れた。

3. 臨床検查所見別の生存率

入院時臨床検査所見のうち, 体温, 血色素量, 血沈, $\mathrm{CRP}$ ，血浆 fibrinogen，血清蛋白分画の 6 つの因子を 選び, 予後との関係を検討した。

体温, 血色素量, 血沈, CRP, fibrinogen の 5 つの 因子についての生存率を表 1 に示す。体温は入院時の 一日の最高体温が $37.1^{\circ} \mathrm{C}$ 以上でほぼ連日続くものを発 
因 1 腎癌全症例の生存率

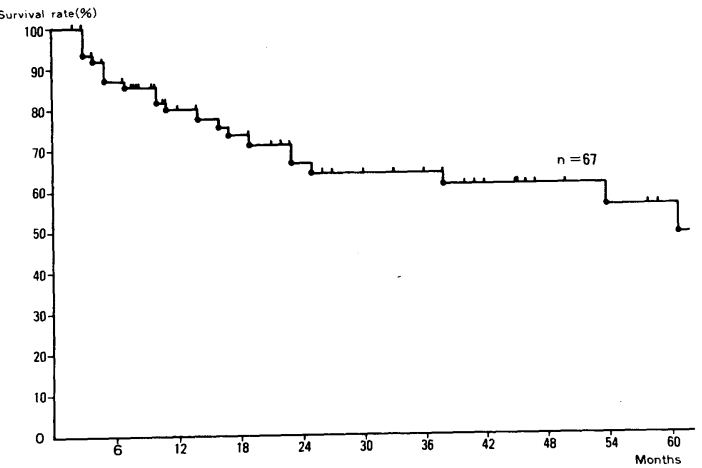

図 2 初発症状による腎癌の生存率

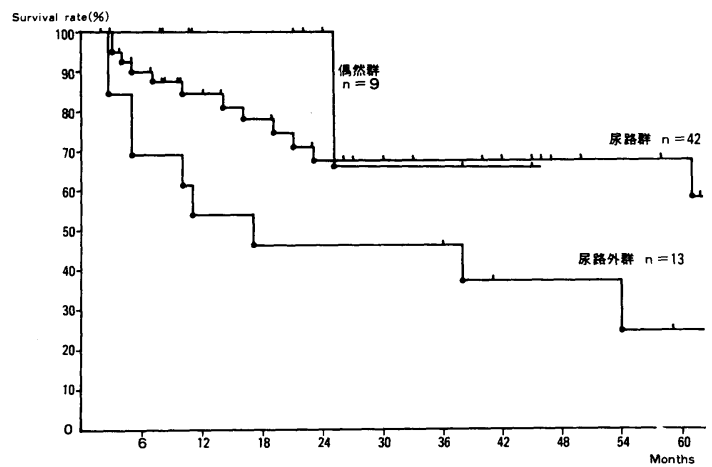

表 1 臨床検査所見による腎癌の生存率

\begin{tabular}{|c|c|c|c|c|c|}
\hline & & 例数 & 1 年生存事 (\%) & 3年生存事 (\%) & 5 年生存事 $(\%)$ \\
\hline \multirow[t]{2}{*}{ 体温 } & 発熱群 & 7 & 100 & 60.0 & 60.0 \\
\hline & 正常詳 & 57 & 77.2 & 64.7 & 55.6 \\
\hline \multirow[t]{2}{*}{ Hemoglobin } & 夌血群 & 10 & 58.3 & $07^{*}$ & $07 *$ \\
\hline & 正常群 & 54 & 83.6 & 73.5 & $63.6-$ \\
\hline \multirow[t]{2}{*}{ CRP } & 隅性群 & 40 & $68.6 \neg *$ & $52.67^{*}$ & $39.9 \square *$ \\
\hline & 陰性群 & 22 & $100 工$ & $91.7-$ & $91.7-$ \\
\hline \multirow[t]{2}{*}{ 血沈 } & 元進群 & 25 & $64.07^{*}$ & $43.37^{*}$ & $37.17^{*}$ \\
\hline & 正常群 & 39 & $91.7-$ & 79.7 & $66.4-$ \\
\hline \multirow[t]{2}{*}{ Fibrinogen } & 高俌群 & 20 & 64.6 & 51.7 & 38.8 \\
\hline & 正常群 & 34 & 83.3 & 74.5 & 55.0 \\
\hline
\end{tabular}

熱群とした，血色素量は $9.9 \mathrm{~g} / \mathrm{dl}$ 以下を㙰血群とした。 血沈は， 1 時間値 $30 \mathrm{~mm}$ 以上の症例を亢進群とした。 CRP は陽性群と陰性群とに分けて検討した。 fibrinogen は200から400mg/dl を正常群, それを越兄 るものを高値群とした。血清蛋白分画による生存率に ついては表 2 に示す, 血色素量, 血沈, CRP, 血清蛋 白分画で異常を示す症例の予後は不良であった，血浆
表 2 血清蛋白分画による腎癌の生存率

\begin{tabular}{|c|c|c|c|c|c|}
\hline & & 例数 & 1 年生存事 (\%) & 3 年生存率 (\%) & 5 年生存丰 (\%) \\
\hline \multirow[t]{2}{*}{ T.P. } & 低傏群 & 21 & 71.4 & 59.5 & 59.5 \\
\hline & 正常群 & 41 & 83.4 & 65.5 & 51.4 \\
\hline \multirow[t]{2}{*}{ Albmin } & 低值詳 & 35 & 73.8 & $55.77^{*}$ & $40.17^{*}$ \\
\hline & 正常群 & 23 & 95.2 & 95.2 & $95.2-$ \\
\hline \multirow[t]{2}{*}{$\alpha_{1}-g \mid b}$. & 高傐群 & 39 & $74.17^{*}$ & $59.07 *$ & 54.5 \\
\hline & 正常群 & 19 & $100-$ & $100-$ & 75.0 \\
\hline \multirow{2}{*}{$\alpha_{2}-\mathrm{g} \mid \mathrm{b}}$. & 高檤群 & 39 & 76.3 & 55.7 & 47.7 \\
\hline & 正常群 & 23 & 90.2 & 83.2 & 74.0 \\
\hline \multirow[t]{2}{*}{$\beta$-glb. } & 高値群 & 17 & 70.6 & 52.9 & 52.9 \\
\hline & 正常群 & 41 & 85.7 & 77.4 & 59.1 \\
\hline \multirow[t]{2}{*}{$\gamma$-glb. } & 高㯈群 & 19 & 66.9 & $34.77^{*}$ & 23.1 \\
\hline & 正常群 & 39 & 88.5 & $84.8-$ & 76.4 \\
\hline
\end{tabular}

図 3 Echo patternによる腎癌の生存率

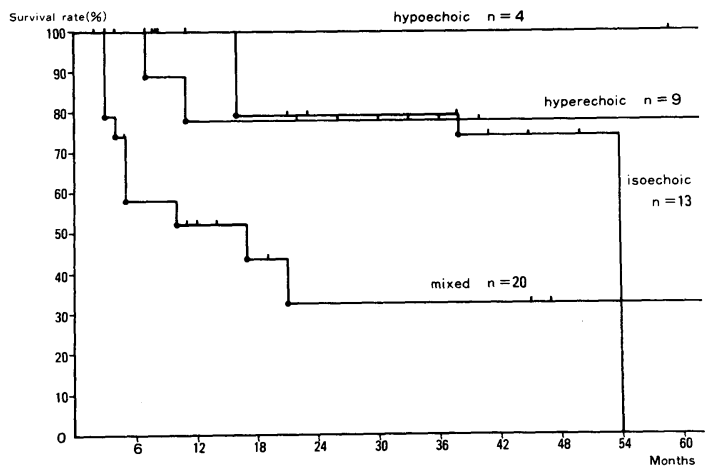

fibrinogen 高値例も有意ではないが，予後不良の傾向 を示した。

4. 画像診断による生存率

画像診断では, 超音波断層法の腫瘍 echo pattern に よる生存率を検討した(図 3 ). echo patternは, 腫瘍 echoがほぼ均一で腎実質より強いものを hyperechoic pattern, 腎実質と同程度のものを isoechoic pattern, 腎実質より弱いものを hypoechoic pattern とした。 なた上記の 3 pattern が混在し，腫瘍 echo が 不均一なるのを mixed pattern とした. mixed pattern を示す腎癌の生存率は他の pattern を示すものに比べ 低い傾向を示したが有意ではなかった。そこで, hyper echoic, isoechoic, hypoechoic pattern を一括して生 存率を計算すると， 1 年， 3 年， 5 年生存率はそれぞ れ90.8\%，85.4\%，50.6\%であった. mixed patternを 示す腎癌は，それぞれ $52.1 \% ， 32.6 \% ， 32.6 \%$ あり， 1 年, 3 年生存率で有意に低値を示した。

5. 病理学的所見による生存率 
図 4 T 分類による腎癌の生存率

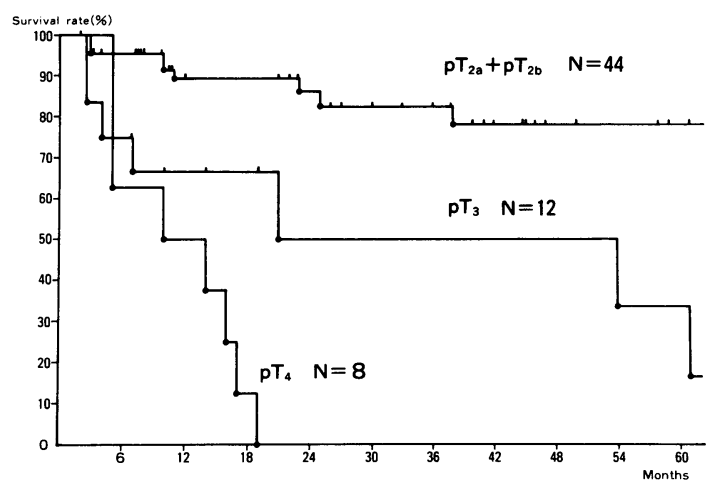

表 $3 \mathrm{~N}$ 分類, $\mathrm{V}$ 分類による腎癌の生存率

\begin{tabular}{|c|c|c|c|c|c|}
\hline & & 例数 & 1 年生存事 (\%) & 3年生存事(\%) & 5年生存事 (\%) \\
\hline $\mathrm{N}$ 分類 & $\begin{array}{l}\text { pNo } \\
\text { pN1,2,3 }\end{array}$ & $\begin{array}{r}55 \\
5\end{array}$ & $\left.\begin{array}{c}86.0 \\
0\end{array}\right]^{*}$ & $\left.\begin{array}{l}75.7 \\
0\end{array}\right]^{*}$ & $\left.\begin{array}{c}57.3 \\
0\end{array}\right]^{*}$ \\
\hline V分類 & $\begin{array}{l}p \vee O \\
p \vee 1 a, 1 b, 2\end{array}$ & $\begin{array}{r}54 \\
7\end{array}$ & $\begin{array}{l}82.3 \\
44.4\end{array}$ & $\begin{array}{c}69.1 \\
-\end{array}$ & $\begin{array}{l}59.5 \\
-\end{array}$ \\
\hline
\end{tabular}

腎癌取扱い規約による進展度, 悪性度, 組織学的細 胞型, 組織学的構築型, 浸潤増殖様式 (Infiltration: INF）と生存率について検討した。

進展度では, 原発腫瘍 ( $\mathrm{T}$ 分類), リンパ節転移 ( $\mathrm{N}$ 分類), 静脈浸潤 ( $\mathrm{V}$ 分類), 遠隔転移 ( $\mathrm{M}$ 分類) 別に 検討した. T 分類による生存率を図 4 に示す.pT2の 1 年生存率は $89.7 \%, 3$ 年生存率は $82.6 \%, 5$ 年生存率 は78.0\%であった。同様に pT3の 1 年, 3 年, 5 年生 存率はそれぞれ $66.7 \%, 50.0 \%, 33.3 \%, \mathrm{pT} 4$ は50.0\%， $0 \%, 0 \%$ あ゙り, 原発腫瘍の進展により生存率は低 下していた. 次に, $\mathrm{M}$ 分類による生存率を図 5 に示す. pM0の 1 年， 3 年， 5 年生存率はそれぞれ $97.8 \%$, $90.7 \%, 77.6 \%$ であり, pM1は35.3\%，5.9\%，5.9\% であった，有転移例の予後は，有意に不良といえた。 一方リンパ節転移を有する症例は 5 例で, pN1が 1 例,

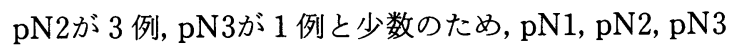
を一括して生存率を計算し, 表 3 に示した。静脈浸潤 を有する症例も, $\mathrm{pV} 1 \mathrm{a}$ が 2 例, $\mathrm{pV} 1 \mathrm{~b}$ が 3 例, $\mathrm{pV} 2$ が 3 例の計 8 例と少なく, pV1a，pV1b, pV2を一括して 表 3 に示した. 少数例ではあるが, リンパ節転移を有 する症例は生存率が低かった。

次に, 悪性度による生存率を図 6 に示す. grade 1 の 1 年生存率は $95.0 \%, 3$ 年生存率は $83.8 \%, 5$ 年生存
図 $5 \mathrm{M}$ 分類による腎癌の生存率

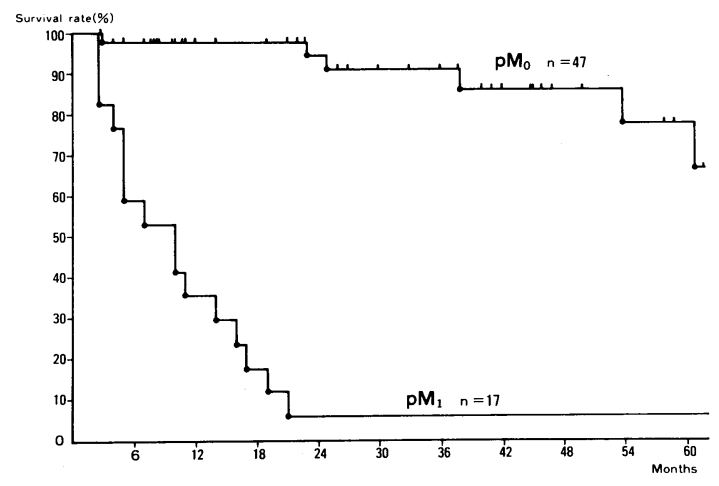

図 6 Grade による腎癌の生存率

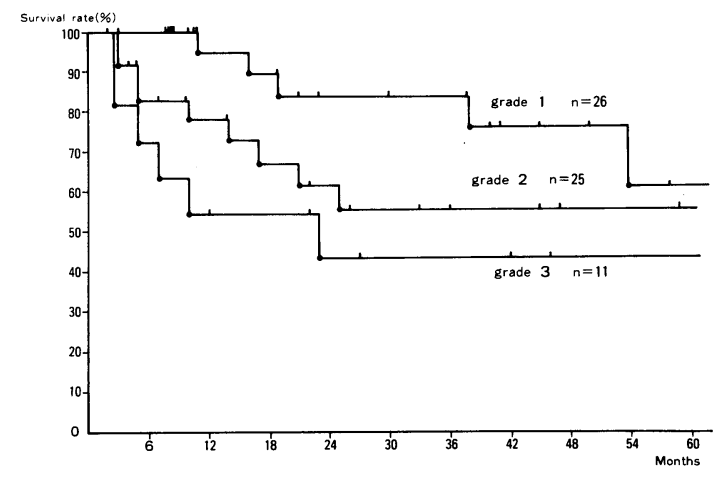

率は61.0\%であった。同様に grade 2 の 1 年, 3 年, 5 年生存率はそれぞれ78.1\%，55.5\%，55.5\%，grade 3 は54.5\%，43.6\%，43.6\%であった。悪性度の高い腫 瘍ほど生存率は低下し, grade 1 grade 3では有意の 差がみられた。

組織学的細胞型, 組織学的構築型, 浸潤増殖様式に よる生存率を表 4 に示す. 組織学的細胞型では, clear cell, granular cell, mixed cell の症例の生存率はほ ぼ同程度であった。しかし，少数例のため検定では有 意ではないが, spindle cell を示す症例の生存率は低 かった。組織学的構築型による生存率では, alveolar type, tubular type, papillary type, cystic type 示す症例の生存率は同程度だが, solid typeを示す症 例は 1 年以内に 4 例中 3 例が死亡し, 予後不良であっ た. 浸潤増殖様式による生存率では, INF $\beta$ を示す症例 が INF $\alpha$ の症例より生存率がやや高かった。これは今 回の INF $\beta$ の症例は全例遠隔転移を有しない $\mathrm{pM} 0 て ゙$ あったためと考えられる. INF $\alpha$ 群の中でも $\mathrm{pM} 0$ の症 
表 4 病理学的所見による腎癌の生存率

\begin{tabular}{|c|c|c|c|c|c|}
\hline & & 例数 & 1 年生存事 (\%) & 3 年生存事 (\%) & 5 年生存事 (\%) \\
\hline \multirow[t]{4}{*}{$\begin{array}{r}\text { 組織学的 } \\
\text { 細胞型 }\end{array}$} & $\begin{array}{l}\text { clear cell } \\
\text { granular }\end{array}$ & 40 & 86.9 & 72.3 & $72.37^{*}$ \\
\hline & cell & 4 & 100 & 50.0 & - \\
\hline & $\begin{array}{l}\text { mixed cell } \\
\text { spindle }\end{array}$ & 17 & 68.8 & 55.0 & 35.4 \\
\hline & cell & 2 & 0 & 0 & - \\
\hline \multirow{5}{*}{$\begin{array}{c}\text { 組緥学的 } \\
\text { 棈築型 }\end{array}$} & alveolar & 45 & 81.0 & 64.8 & 47.5 \\
\hline & tubular & 7 & 100 & 80.0 & 80.0 \\
\hline & papillary & 3 & 100 & 100 & 100 \\
\hline & cystic & 1 & 100 & 100 & - \\
\hline & solid & 4 & 25.0 & 25.0 & - \\
\hline \multirow[t]{3}{*}{ 漫洞嵄式 } & $\alpha$ & 48 & 83.4 & 66.8 & $32.3 \square^{*}$ \\
\hline & $\beta$ & 7 & 85.7 & 85.7 & 85.7 \\
\hline & $\gamma$ & 5 & 40.0 & 40.0 & 40.0 \\
\hline
\end{tabular}

図 7 根治的腎摘除術後の補助療法の有無による生存 率

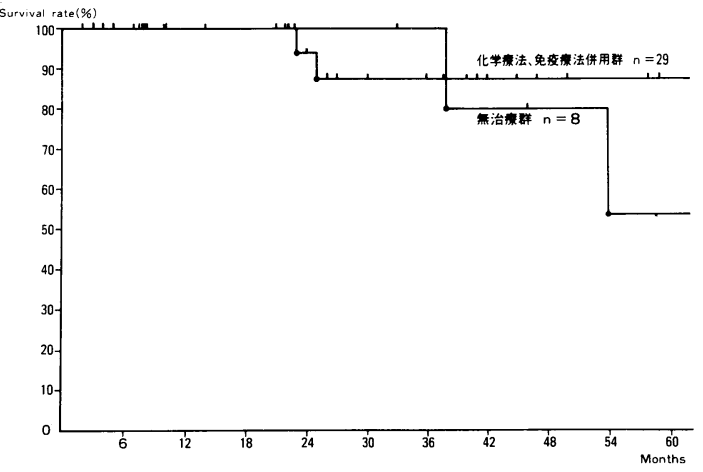

例と INF $\beta$ の症例の生存率を比較するとほぼ同程度 である。それに対し，INF $\gamma$ を示す症例は全例 pM1で あり，予後不良の傾向を示した。

6. 治療法による生存率

今回の検討では, 根治的腎摘除術施行症例の術後補 助療法の相違による生存率と遠隔転移のある進行腎癌 に対する interferon- $\alpha$ (IFN- $\alpha$ )の使用の有無による生 存率の検討を行った。

術後補助療法として当施設では，原則的には化学療 法（FT 207，5-FU またはUFT）と非特異的免疫療法 (OK-432)の併用を行っている.しかし副作用, 患者の 拒否, 通院回数が少ないなどの理由により, 免疫療法, 化学療法をともに行っていない，またはどちらか片方 だけ行っている症例がある。それらの症例と, 免疫療 法, 化学療法を併用している症例の生存率を比較した ものが図 7 である. 生存率でみる限りでは, 両者併用 群と無治療群に差はない。しかし, 併用群では29例中
図 8 遠隔転移を有する腎癌に対する IFN- $\alpha$ の効果

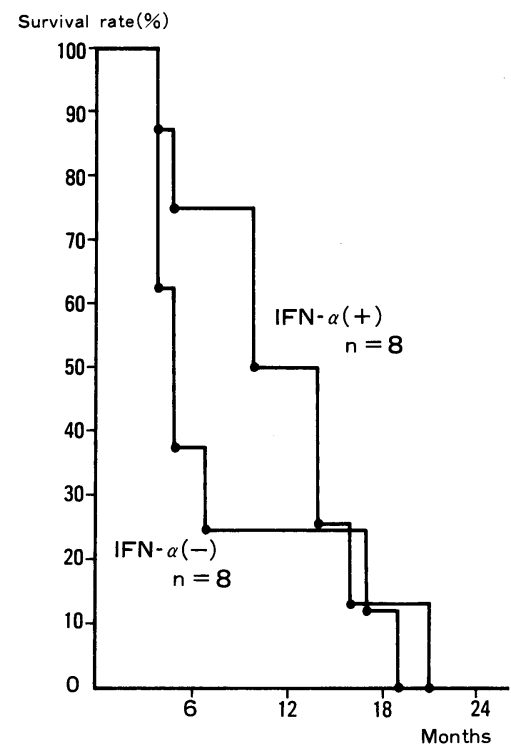

2 例が術後約 2 年で死亡しているだけであるのに対 し, 無治療群では 8 例中 2 例が術後約 3 年と 4 年で死 亡していた。

進行腎癌に対しては，8例に IFN- $\alpha$ を使用した。こ のらち非根治的腎摘除術を施行した症例は 5 例であ る.それに対し, 化学療法, ホルモン療法を行った進 行腎癌も 8 例であった. こちらも 8 例中 5 例に非根治 的腎摘除術を施行した。 その生存率を図 8 に示す。両 群とも差はなく予後不良だが, IFN- $\alpha$ 使用群のほらが 生存期間のやや長い症例がみられた。

\section{考察}

腎癌の治療成績についての最近の報告では, 1 年生 存率 $67 \sim 84 \%, 3$ 年生存率 $49 \sim 61 \%, 5$ 年生存率

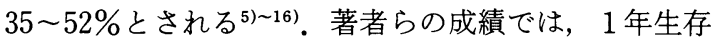
率 $79.8 \%, 3$ 年生存率 $64.1 \%, 5$ 年生存率 $55.5 \%$ で, これらの成績と比べると, 若干成績が良いようである. この原因として，本検討の症例は low stage の腎癌が 多かったことが考えられる。他の報告と比較するため, Robson らの stage 分類 ${ }^{17)}$ に準じて今回の対象症例を 分類すると, stage 1は56.6\%, stage 2 は $9.0 \%$, stage 3は7.5\%, stage 4は26.9\%であった。他の報告によれ ば5)7)11) 20), stage 1は28〜57\%, stage 2 は $723 \%$, stage 3 は 9 42\%, stage 4は11〜37\%とばらつきがあ る.しかし, 最も多いのは stage 1が約30〜40\%, stage 2 が約10\%, stage 3が約20〜30\%, stage 4が約30〜40\% 
であり, 今回の症例に比べ, high stage の症例の比率 が高い。このことが生存率に影響しているものと考光 られ, 腎癌の早期発見の重要性が示唆される。

今回の対象症例に low stage の症例が多い理由の一 つとしては，超音波断層法などによる腎癌の早期発見 が挙げられる。今回偶然群とした11例は，検診などに よる超音波断層法で発見されたものが注とんどであ り,これらの症例はいずれも low stage であった.

腎癌の予後に影響する因子としては，宿主側の因子 として，尿路外症状，血色素量，血沈，CRP，血清蛋 白分画などが諸家により報告されてきだ(6) 8)16)21)，血 沈，CRP，血清蛋白分画については，諸家の報告と同 様に，自験例でも生存率に差がみられた。尿路外症状 については，著者らはすでにその重要性を強調してき た7). 今回の症例では, 有意な差はなかったが尿路外症 状を示す症例の予後は不良でありその重要性は変わり ないものと考党る．血浆 fibrinogen についても著者ら はその有用性について報告したが21). 今回の検討でも 予後と相関する傾向がみられた。

腫瘍側の因子としては, echo pattern, 病理学的所 見について検討した. echo patternについてはすでに 報告している通り ${ }^{22)}$, 予後と関連がみられた. mixed pattern は腫瘍の急速な進展を示す所見と考兄られ た.

病理学的所見として, 進展度, 悪性度, 組織学的細 胞型, 組織学的構築型, 浸潤様式をとりあげ, 生存率 との関係について検討したが, 進展度, 悪性度と生存 率の相関は諸家の報告ですでに認められてい $ろ^{7) \sim 19)}$. 諸家の報告では, 進展度は Robson らの分類, 悪性度はSkinner らの分類 ${ }^{14)}$ に準じていることが多 く, 本検討で行った分類とは異なるが進展度, 悪性度 の生存率の低いことに変わりはない，一方, 組織学的 細胞型, 組織学的構築型については多くの分類法があ り, 生存率との関係は必ずしも一定しない，細胞型は clear cell type の方が granular cell type や mixed cell type より 5 年生存率は良いとするもの ${ }^{14)}$ と, 細胞 型に無関係とするものがある. granular cell type の方 が良いとするものもある ${ }^{1213)}$. 自験例では cell type と 生存率には関係ないようであったが，一般的にも， clear cell type と granular cell type の予後はほぼ同 程度で, spindle cell type の予後だけが不良とされる。

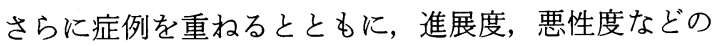
他の因子も考慮に入れて検討が必要と思われる。構築 型についても，分類法が多くあり，生存率との関係は
はっきりしないが, solid typeの予後が不良といら報 告が多く12)14)19), 本報告結果と一致した。浸潤増殖様式 と生存率の関係については，まとまった報告はみられ ないが，自験例の INF $\gamma$ の 5 例中 4 例が遠隔転移を示 し，明らかに予後不良であった。

腎癌の治療法としては，根治的腎摘除術が最も確実 な治療法であるが, 術後再発もみられ補助療法の必要

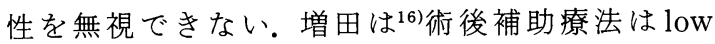
stage かつ low grade の腎癌には原則的に必要無いと しているが, low stage の腎癌中に再発, 転移の risk に 関して grade の他にも heterogeneity が存在すると考 えられることから ${ }^{20)}$ ，著者らはその場合でも原則的に 行らことにしている. 使用薬剤としては OK-432と FT 207，5-FUまたはUFT の併用を行っているが，FT 207, UFT は腎癌に有効であった症例も報告されてい る2324).これらの薬剤は, 副作用が少なく, 経口投与が できて外来でも使用しやすい。乙かし生存率に差はな いものの, 現在のところ両者併用群の死亡症例数は 29 例中 2 例であるのに対し無治療群は 8 例中 2 例と両者 併用群に死亡症例数が少ないことから, 補助療法とし て術後両者併用を行ってよいものと考觉る。

Interferonは, 進行腎癌に有用な薬剤とされ, Interferon に反応する症例（responder）の予後は良好とさ れる ${ }^{1)}$. 本研究では少数例のため Interferonに対する responder と non responderに分けた検討は行わな かった。しかし自験例では, 進行腎癌に Interferonを 投与しても必ずしも延命効果が期待でさるわけではな かった。さらに生存率を向上させるためには,インター ロイキン 2 などを併用した新しい治療が必要であろ 5.

\section{結 語}

腎癌の自験例67例について治療成績を検討した，予 後に影響するいくつかの因子について検討した結果, 貧血, 血沈六進, CRP 陽性, 血清アルブミン減少, 血 清 $\alpha_{1}$ グロブリン上昇, 超音波断層法で腫瘍が mixed patternを示す症例の予後は不良であった。 また病理 学的検討では, 腫瘍の進展度と悪性度は予後に影響す る重要な因子であった。腎癌の根治的腎摘除術後に, 化学療法 (FT 207，5-FU またはUFT) と非特異的免 疫療法 (OK-432：Picibanil）を併用した補助療法は腎 癌の予後改善に有用と思われた。

な打本論文の要旨は, 著者の一人増田が第 25 回日本癌治 療学会で発表した. 


\section{文献}

1) Umeda, T. and Niijima, T.: Phase II study of alpha interferon on renal cell carcinoma-Summary of three collaborative trials. Cancer, 58, 1231-1235, 1986.

2）大見嘉郎，畑 昌宏，太田信隆，鈴木和雄，田島 惊, 藤田公生, 阿曾佳郎：原発巣摘除後骨㧍よび肺 転移巣の消退をきたした腎癌の 1 例。泌尿紀要, 28, 731-736, 1982.

3) 日本泌尿器科学会, 日本病理学会, 日本放射線学 会：腎癌取扱い規約。第 1 版。金原出版, 東京, 1984.

4）麦谷荘一，関口 浩，金子佳雄，秋山敏一，杉山 高, 鈴木俊秀, 增田宏昭, 田島 惊, 阿曾佳郎：超 音波断層法により発見された腎細胞癌25症例の検 討。日泌尿会誌，印刷中.

5）阿曾佳郎，田島 惇：腎癌の治療成績とそれを左 右する因子，癌の臨床，27，867-876，1981.

6）阿曾佳郎，小磯謙吉, 岡田清己, 星野嘉伸, 村橋 勲：予後からみた腎癌手術と化学療法および放射 線療法併用の評価。日泌尿会誌，65，209-217， 1974.

7）阿曾佳郎：腎癌に対する腎摘と抗癌剂療法, 放射 線療法併用効果の検討. 日泌尿会誌, 69, 1167-1168, 1978.

8）高安久雄, 小川秋実, 上野 精, 岸 洋一, 東原英 二：腎尿管腫瘍の治療成績。日泌尿会誌，69, 417-425, 1978.

9) Rafla, S.: Renal cell carcinoma. Cancer, 25, 26-40, 1970.

10) Kay, S. : Renal carcinoma. Am. J. Clin. Path., 50, 428-432, 1968

11）里見佳昭, 仙賀 裕, 福田百邦, 中橋 満, 西村隆 一, 大島博幸, 近藤猪一郎, 吉邑貞夫, 福島修司, 古畑哲彦, 石塚栄一, 福岡 洋: 腎癌患者の 10 年生 存率及び 10 年以上生存例の検討。日泌尿会誌, 75 , 118-125, 1984.

12) Boxer, R.J., Waisman, J., Lieber, M.M., Mampaso, F.M. and Skinner, D.G.: Renal Carcinoma: Computer analysis of 96 patients treated by nephrectomy. J. Urol., 122, 598-601, 1979.
13) McNichols, D.W., Segura, J.W. and DeWeerd, J. $\mathrm{H}$. : Renal cell carcinoma : Longterm survival and late recurrence. J. Urol., 126, 17-23, 1981.

14) Skinner, D.G., Colvin, R.B., Vermillion, C.D., Pfister, R.C. and Leadbetter, W.F.: Diagnosis and management of renal cell carcinoma-A clinical and pathological study of 309 cases. Cancer, 28, 1165-1171, 1971.

15) Katz, S.A. and Davis, J.E.: Renal adenocarcinoma. Urology, 10, 10-11, 1977.

16）増田富士男：腎腫瘍の治療をめぐる諸問題。日泌 尿会誌，76，1612-1618，1985.

17) Robson, C.J., Churchhill, B.M. and Anderson, W.: The results of radical nephrectomy for renal cell carcinoma. J. Urol., 101, 297-301, 1969.

18) Waters, W.B. and Richie, J.P.: Aggressive surgical approach to renal cell carcinoma: Review of 130 cases. J. Urol., 122, 306-309, 1979.

19）大西哲郎, 町田豊平, 増田富士男：腎細胞癌の病理 組織学的検討一第 2 報. 病理組織像と予後. 日泌尿 会誌，74，2097-2106， 1983.

20）阿曾佳郎：腎細胞癌治療についての Over-view. 泌尿器がん化学療法の進歩々問題点, 吉田 修, 阿 曽佳郎, 友吉唯夫, 岡島英五郎, 小幡浩司, 片山 喬, 岡田謙一郎, 古武敏彦 編, p. 13, 蟹書房, 東 京, 1987.

21）鈴木明彦, 増田宏昭, 大田原佳久, 鈴木和雄, 田島 惊, 阿曾佳郎: 腎癌と血中腫瘍マーカ一. 日泌尿会 誌, 77, 87-91，1986.

22）増田宏昭：腎癌に抢ける超音波断層法による術前 Stage 診断と腫瘍 Echo pattern の意義. 日泌尿会 誌，78，1675-1681，1987.

23）里見佳昭, 仙賀 裕, 福田百邦, 中橋 満, 大島博 幸, 古畑哲彦：腎細胞癌の化学療法一第 3 報. FT 207, vinblastine 単独療法。日泌尿会誌, 75, 903-908, 1984.

24）増田富士男, 鈴木正泰, 仲田浄治郎, 望月 篤, 近 藤 泉：UFTによる腎細胞癌肺転移巣の完全退 縮例。日泌尿会誌，78，1266-1269，1987。

（1988年 1 月 12 日受理） 